\title{
Viral abundance in aquatic systems: a comparison between marine and fresh waters
}

\author{
Roxane Maranger, David F. Bird \\ Département des sciences biologiques, Université du Québec à Montréal, CP 8888, Succ. 'A', Montréal, \\ Québec, Canada H3C 3P8
}

\begin{abstract}
In order to investigate the factors controlling viral abundance, 22 lakes in Québec were surveyed. We measured viral and bacterial abundance, bacterial production, chlorophyll $a$, total phosphorus and DOC (dissolved organic carbon) concentrations. Regression models built with these data were compared to models based on literature data, which to date have been collected largely from marine sites. Positive empirical relationships were found between viral abundance and (1) chlorophyll $a$ concentrations, (2) bacterial abundances, (3) bacterial production, and (4) total phosphorus concentration. There was little to no trend in the virus-to-bacteria ratio with increasing trophy. Analysis of covariance revealed significant differences between relations in marine and freshwater systems. The virusto-bacteria ratio was significantly higher in freshwater (mode $=22.5$ ) than marine environments (mode $=2.5$ ), and there were significantly more bacteria per unit chlorophyll in our freshwater samples We suggest that this difference is related to the increased dependence of freshwater bacteria on allochthonous material relative to marine systems, as well as the increased relative importance of photosynthetic cyanobacteria in lakes.
\end{abstract}

KEY WORDS: Virus Bacteria Chlorophyll a Bacterial production - Marine Freshwater - Empirical relationships

\section{INTRODUCTION}

In the past decade and a half, considerable effort has been applied to identify the factors which control bacterial populations in aquatic systems. This effort stems from the realization of the important role of heterotrophic bacteria as decomposers and remineralizers and as a source of particulate organic carbon (POC) through their rapid assimilation of dissolved organic carbon (DOC) and their efficient conversion of this DOC into bacterial biomass. From this recognition of bacteria as an integral component of aquatic systems, Azam et al. (1983) formulated the microbial loop hypothesis wherein significant amounts of DOM (dissolved organic matter) produced by algae are assimilated by bacteria. Bacteria are in turn grazed upon by flagellates, ciliates and macrozooplankton, thereby reintroducing 'lost' carbon back into the food chain (Fenchel 1982). Empirical studies support several predictions about bacterial abundance and activity brought forth by the microbial loop hypothesis. Included among these relationships is the increase in bacterial abundance with increasing chlorophyll $a$ and total phosphorus concentrations (Bird \& Kalff 1984, Del Giorgio \& Peters 1993). In addition, an increase in bacterial production has been observed with an increase in (1) net primary production (Cole et al. 1988), (2) bacterial abundance (White et al. 1991), and (3) DOC concentration (Tranvik 1992). Generally these relationships are consistent across aquatic systems.

Until recently, bacterial community size was thought to be controlled largely by flagellate and ciliate grazing (Fenchel 1982, McManus \& Fuhrman 1986, Pace 1988). However, there appear to be inconsistencies with the budgets which attempt to balance bacterial production and the removal of bacteria by grazers (Sherr et al. 1989), suggesting that bacteria are also being removed from the system by other means.

Viruses have recently been identified as dynamic components of aquatic environments. High viral abun- 
dances have been observed in marine (Bergh et al 1989, Proctor \& Fuhrman 1990), coastal (Suttle et al. 1990, Paul et al. 1991), and fresh waters (Klut \& Stockner 1990), marine (Paul et al. 1993) and freshwater sediments (Maranger unpubl. data) and in polar sea ice (Maranger et al. 1994). The high concentration of viruses in aquatic systems along with rapid changes in viral abundances (Børsheim et al. 1990, Bratbak et al. 1990), rapid viral decay rates (Heldal \& Bratbak 1991) and the direct demonstration of virus particles within bacterial cells imply that viruses play an important role in the control of bacterial populations. Suttle \& Chen (1992) estimated that viruses are responsible for 8 to $26 \%$ of bacterial mortality; Proctor et al. (1993) set it at 6 to $62 \%$.

Despite increasing research on aquatic viruses, little work has been done to model changes in virus concentrations with the important parameters affecting bacterial production and abundance. In this study, we sampled 22 lakes in Québec and collected literature data in an attempt to model changes in viral abundance with (1) chlorophyll a concentrations, (2) bacterial abundance, (3) total phosphorus and (4) DOC concentrations, all of which are parameters known to control bacterial production. We also determined whether viral abundance could be predicted empirically from bacterial production.

\section{MATERIALS AND METHODS}

Sampling sites and methods. Samples were collected from 22 lakes with a total of 23 sites, 12 located in the Laurentian Mountains and 11 in the Eastern Townships, north and east of Montréal, Québec, respectively between July 24 and August 8, 1993

Samples for measuring bacterial production were taken at $1 \mathrm{~m}$ using a Van Dorn bottle. All other water samples were taken using an integrated water column sampler (Tygon tubing, inner diam. $3 \mathrm{~cm}$ ). The integrated sample was taken from $0 \mathrm{~m}$ to twice the Secchi depth, in order to sample most or all of the euphotic zone.

Virus and bacteria samples were fixed with glutaraldehyde ( $2.5 \%$ final concentration); total phosphorus samples were taken directly, and DOC samples were prefiltered in the field through a $0.45 \mu \mathrm{m}$ syringetip filter and acidified with concentrated nitric acid. All samples were stored at $4^{\circ} \mathrm{C}$ until processed which was within 1 mo of collection. Total phosphorus concentration was determined using an Alpkem auto-analyzer and DOC concentrations were determined using a Dohrmann carbon analyzer.

Enumeration of bacteria and viruses. Bacteria were stained with DAPI ( $\left.1 \mu \mathrm{g} \mathrm{ml}^{-1}\right)$ and filtered onto black
$0.2 \mu \mathrm{m}$ pore size polycarbonate filters (Porter \& Feig 1980). Samples were enumerated using epifluorescence microscopy at a final magnification of $1250 \times$.

Viruses were pelleted directly onto 400-mesh formvar-coated $\mathrm{Cu}$ grids at $100000 \times \mathrm{g}$ for $30 \mathrm{~min}$ using an EM-90 rotor in a Beckman airfuge (Hammond et al. 1981). Grids were air dried, stained with $2 \%$ uranyl acetate for 5 min and counted directly using a Phillips EM 300 transmission electron microscope at high magnification $(90000 \times)$. Recovery efficiency of the EM-90 rotor was established at $96 \%( \pm 19 \%)$ by pelleting a known concentration of T5 phage, an extensively studied lytic phage of Escherichia coll. Viral abundance was estimated by observing 50 fields per EM grid. Two grids per sample were prepared in which viruses from 5 fields in 10 grid squares were enumerated. The coefficient of variation of the mean count per sample using this method was less than $10 \%$. Viruses from the Québec lakes were grouped into the following size classes as determined by head capsid diameter: $<50 \mathrm{~nm}, 50-70 \mathrm{~nm}, 70-100 \mathrm{~nm}$, and $>100 \mathrm{~nm}$.

Bacterial production. Production was measured in the field using ${ }^{3} \mathrm{H}$ leucine (Kirchman et al. 1985). Two replicates and 2 controls killed with cold trichloroacetic acid (TCA; $5 \%$ final concentration) and formaldehyde ( $1 \%$ final concentration) were incubated for $2 \mathrm{~h}$ at ambient lake water temperature. Approximately $10 \mathrm{nmol} \mathrm{l}^{-1}$ final of labelled leucine with a specific activity of $54 \mathrm{Ci} \mathrm{mmol}^{-1}$ was added to $15 \mathrm{ml}$ samples. Incubation was terminated with the addition of TCA and formaldehyde to final concentrations of 5 and $1 \%$ respectively. Fixed samples were kept at $4^{\circ} \mathrm{C}$ and were filtered onto $0.2 \mu \mathrm{m}$-pore cellulose nitrate filters immediately upon returning to the lab. These filtered samples were washed 3 times with 5\% TCA and twice with $80 \%$ ethanol (Wicks \& Robarts 1988). Filters were dissolved in ethyl acetate and assayed for radioactivity by liquid scintillation.

Algal biomass. Chlorophyll a samples were collected in brown bottles and kept at $4^{\circ} \mathrm{C}$. These were filtered on glass fiber filters immediately upon returning to the lab and kept frozen until processed. Filters were ground in cold acetone (80\%) and centrifuged in a clinical centrifuge. Supernatants were read spectrophotometrically using the trichromatic method as outlined in Wetzel \& Likens (1991).

Literature data collection. Simultaneous observations of viral and bacterial abundances and chlorophyll a concentrations were assembled from the recent literature. Chlorophyll data was not always available. The data were obtained from 14 separate studies covering a relatively wide geographic range of sites (Bergh et al. 1989, Bratbak et al. 1990, Hara et al. 1991, Heldal \& Bratbak 1991, Smith et al. 1992, Wommack et al. 1992, Boehme et al. 1993, Cochlan et al. 1993, Paul et al 1993, Wein- 
bauer et al. 1993, Jiang \& Paul 1994). New observations included the present study and unpublished data collected as part of the Long Term Ecosystem Research (LTER) program in the Antarctic, and from the Hawaiian Ocean Time-series. All values were restricted to the photic zone and in cases where coastal profiles were available, a mean value for bacterial and viral abundance was taken from the upper $30 \mathrm{~m}$. Single site observations were not excluded. Although data from all seasons were included for marine sites, only summer observations were found for freshwater.

Statistical analysis. The data were analysed by ordinary least squares regression analysis and analysis of covariance (ANCOVA) using SAS (SAS Institute Inc 1987). The data were log transformed to meet the normality assumptions of least squares regression analysis and to equalize the variance over the range of observations

\section{RESULTS}

Bacterial abundance was a moderately good predictor of viral abundance (Fig. 1). The overall relationship is:

$$
\log v i r=0.90+0.99 \log b a c \quad r^{2}=0.64, \mathrm{n}=176
$$

where vir is the number of virus-like particles $\left(\mathrm{ml}^{-1}\right)$ as determined by transmission electron microscopy and bac is number of bacteria $\left(\mathrm{ml}^{-1}\right)$. However, many of the observations which fell below the line of prediction came from studies in which the the virus samples were concentrated by ultrafiltration before enumeration by electron microscopy (Fig. 1). It has been reported in several studies that recovery is not $100 \%$ efficient when samples are concentrated, but may be between 13 and $60 \%$ (Suttle \& Chan 1994) or higher (Paul et al 1991). An analysis of covariance (ANCOVA) revealed a significant difference in the intercept but not in the slope of the viral and bacterial relationship when virus samples were concentrated as compared with the relationship when virus samples were not concentrated $\left(\mathrm{r}^{2}=0.69, \mathrm{n}=149, F\right.$ prob. 0.0001). This comparison was done only between concentrated and non-concentrated virus samples from marine observations. These relationships were:

Non-concentrated:

$\log v i r=1.32+0.93 \log b a c \quad n=94$

Concentrated:

$$
\log \text { vir }=0.87+0.93 \log \text { bac } \quad \mathrm{n}=55
$$

Based on the adjusted mean difference between the methods for determining viral adundance from the ANCOVA, for a given bacterial abundance, viral abundances from the non-concentrated counts were about

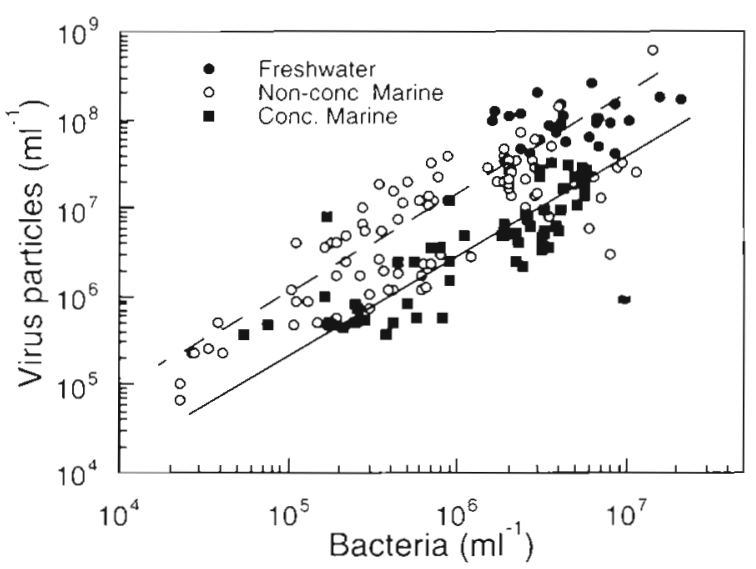

Fig. 1. Relationship between viral and bacterial abundance in fresh- and salt water habitats. An ANCOVA revealed a significant difference in the intercept between estimates based on non-concentrated marine virus samples (represented by the fitted dotted regression linel, and those that had first been concentrated (represented by the fitted solid line). Concentrated virus samples gave significantly lower counts for a given bacterial abundance

2.9 times greater than those from the concentrated counts. To account for the possible underestimation of viruses in concentrated samples, we multiplied those viral abundances, which accounted for 55 observations, by a correction factor of 2.9 as determined by the higher intercept of the non-concentrated samples in the analysis of covariance. All subsequent analyses were done with the corrected viral abundances.

Repeating the analysis with corrected virus values, a fairly strong relationship was found between bacterial and viral abundance (Fig. 2). The overall relationship is

$$
\log \text { vir }=0.95+1.01 \log b a c r^{2}=0.72, n=176
$$

An analysis of covariance revealed a significant difference in both the slope and the intercept of the viral and bacterial relationship in freshwater as compared with marine sites $\left(r^{2}=0.77, n=176, p<0.0001\right)$. These relationships were:

$$
\begin{array}{lll}
\text { Marine: } & \log v i r=1.33+0.93 \log b a c & \mathrm{n}=149 \\
\text { Freshwater: } & \log v i r=6.88+0.16 \log b a c & \mathrm{n}=27
\end{array}
$$

Viral abundance increased with increasing bacterial numbers in marine environments. According to our values, this relationship, as determined through ordinary least squares regression analysis, was not significant for freshwater. Mean abundance of virus-like particles did not change with increasing bacterial numbers in our study lakes (Fig. 3).

An unexpected result was that chlorophyll a concentration was a slightly better predictor of viral abundance in all habitats than was bacterial number. We 


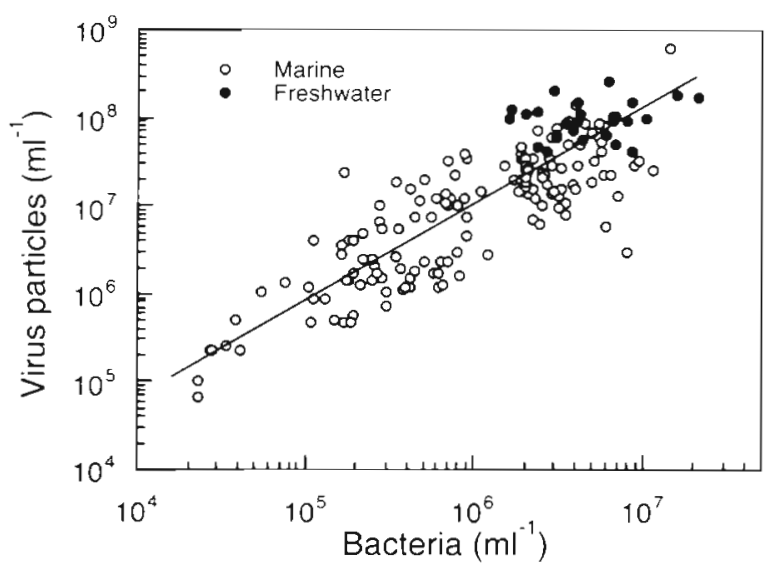

Fig. 2. Relationship between viral and bacterial abundance in fresh- and salt water habitats, including the corrected values for the concentrated marine virus samples. The fitted line represents the regression equation we derived from the overall relationship

found moderately strong empirical relationships between viral abundance and chlorophyll (Fig. 4). The overall relationship is:

$$
\log \text { vir }=7.09+0.80 \log \text { chl a } \quad r^{2}=0.77, \mathrm{n}=101
$$

where chl $a$ is the concentration of chlorophyll $a$ $\left(\mu \mathrm{g}^{-1}\right)$. However, based on our results, the relationship is different in the 2 environments. An analysis of covariance revealed a significant difference in the intercept but no significant difference in the slopes between marine and freshwater environments $\left(\mathrm{r}^{2}=\right.$ $0.79, \mathrm{n}=101, \mathrm{p}<0.0001)$. The 2 models are:

$$
\begin{array}{lll}
\text { Marine: } & \log v i r=7.05+0.73 \log \text { chla } & \mathrm{n}=78 \\
\text { Freshwater: } & \log v i r=7.30+0.73 \log \text { chla } & \mathrm{n}=23
\end{array}
$$

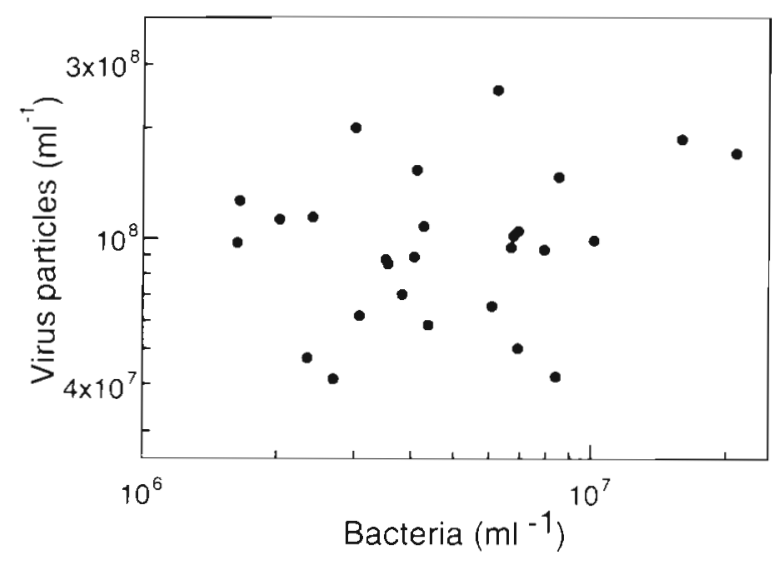

Fig. 3. Viral and bacterial abundances in 22 Québec freshwater lakes. The relationship was statistically nonsignificant

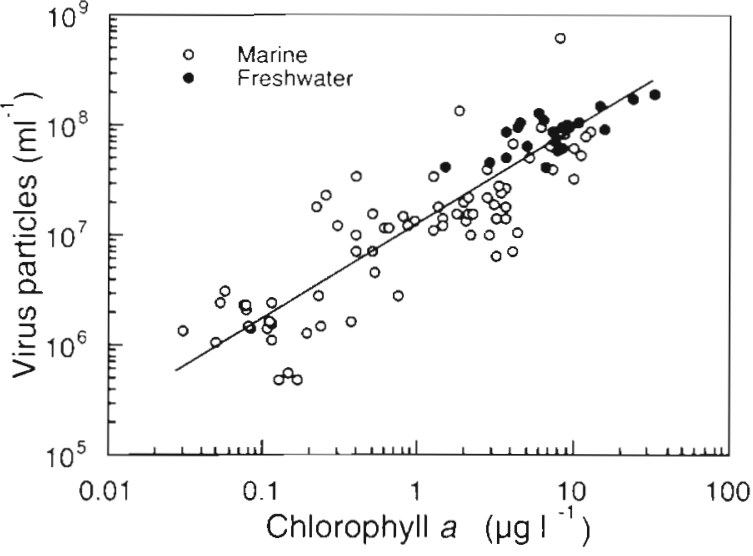

Fig. 4. Scatter diagram of the points obtained from the literature and this freshwater study used to derive regressions of viral abundance and chlorophyll a concentration. Solid line represents the overall regression equation we derived

Based on the adjusted mean between the 2 groups from the ANCOVA, for a given chlorophyll concentration, viral abundance is expected to be about 1.8 times greater in freshwater than marine environments.

Both chlorophyll a concentration and bacterial abundance were significant factors in explaining viral abundance when included in a multiple regression. The model is:

$$
\begin{gathered}
\log \text { vir }=4.97+0.51 \log c h l a+0.34 \log b a c \\
r^{2}=0.80, n=101
\end{gathered}
$$

There was no significant relationship between viral abundance and bacterial abundance in our lakes (Fig. 3, model 3: Freshwater), however there were significant positive relationships between viral abundance and (1) chlorophyll a concentration, (2) bacterial production and (3) total phosphorus for these same sites (Fig. 5A to C). The models for these relationships are:

$$
\begin{array}{ll}
\log \text { vir }=7.55+0.45 \log \text { chla } & \mathrm{r}^{2}=0.52, \mathrm{n}=23 \\
\log \text { vir }=9.37+0.47 \log \text { prod } & \mathrm{r}^{2}=0.52, \mathrm{n}=18 \\
\log \text { vir }=7.50+0.44 \log T P & \mathrm{r}^{2}=0.57, \mathrm{n}=18
\end{array}
$$

where prod is bacterial production $\left(\mu \mathrm{g} \mathrm{C} \mathrm{ml} l^{-1} \mathrm{~h}^{-1}\right)$, and $T P$ is total phosphorus $\left(\mu \mathrm{g} \mathrm{l}^{-1}\right)$. No significant multivariate models were found with our freshwater parameters. No significant relationship was found between viral abundance and DOC

The size class distribution of the viruses of the 23 sites we sampled varied among sites, although viruses $<70 \mathrm{~nm}$ in diameter were dominant (more than $80 \%$ of the observed virus particles) in all cases (Fig. 6). No statistically significant trend in size class distribution in viruses was detected with increasing trophy. 

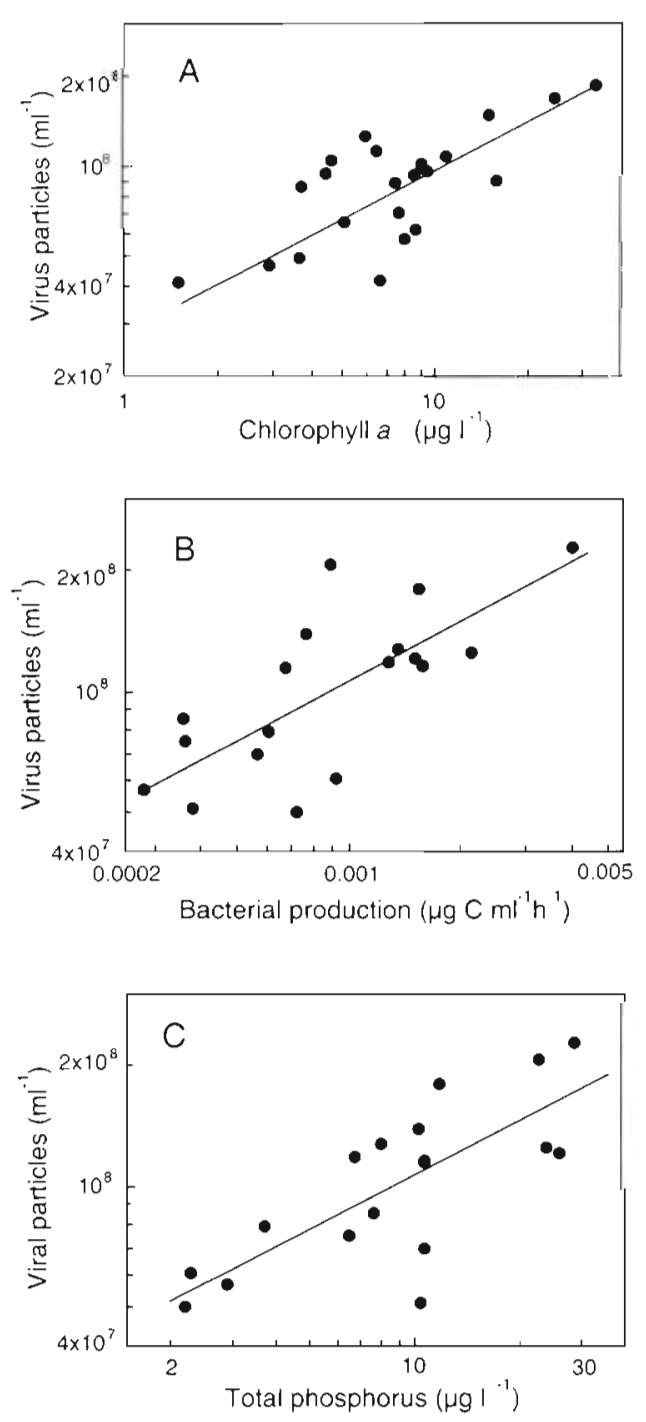

Fig. 5. (A) Relationship between viral abundance and chlorophyll a concentration in our freshwater lakes. (B) Relationship between viral abundance and bacterial production as determined through leucine incorporation in the Québec lakes. (C) Scatter diagram of viral abundance and total phosphorus concentration in freshwater lakes. Solid lines represent the regression equation we derived for each relationship

Interestingly, the virus-to-bacteria ratio (VBR) was significantly higher in freshwater than marine waters ( $t$-test, $\mathrm{p}<0.0001)$. Mean, maximum, and minimum values of viral and bacterial abundances, VBR, and chlorophyll a concentrations for both marine and freshwater habitats are listed in Table 1 . The difference in VBR between environments is evident from the frequency distribution of the VBR (Fig. 7). We did detect a very slight, but significant $(p<0.05)$ trend of chlorophyll $a$ on the VBR (Fig. 8). The overall relationship is:

$\log V B R=1.01+0.14 \log$ chl $a \quad r^{2}=0.08, \mathrm{n}=101$

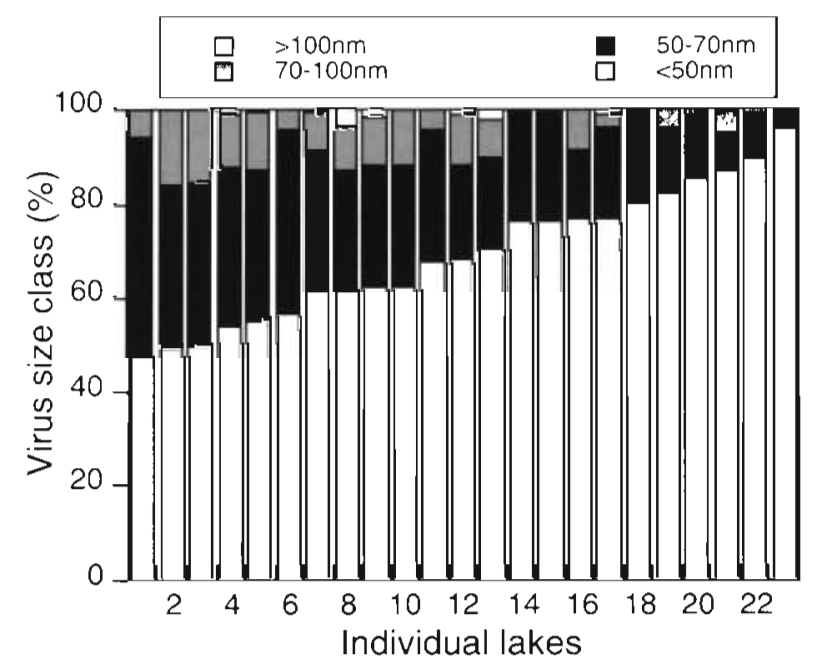

Fig. 6. Viral size class distribution, represented as a percentage of each size class, from the 22 lakes surveyed; 2 bays from Lake Memphremagog were sampled accounting for the 23 sites represented here

We did not detect any significant trend in the overall relationship of VBR with increasing bacterial abundance (Fig. 9). There was a significant negative trend of the VBR with increasing bacterial abundance in our freshwater sites (Fig 9). Chlorophyll a concentration and bacterial abundance were significant parameters in a multiple regression explaining changes in the VBR. Based on the coefficients of this model, increasing chlorophyll concentration has a significant positive effect on the VBR when the influence of bacterial abundance is removed, while increasing bacterial abundance has a significant negative effect when the influence of chlorophyll $a$ is removed. The overall relationship is:

$$
\begin{gathered}
\log V B R=4.82+0.56 \log c h l a-0.63 \log b a c \\
r^{2}=0.18, n=101
\end{gathered}
$$

When this multiple regression was included in an ANCOVA in order to determine any differences between marine and freshwaters, we found a significant difference in the intercepts between the 2 habitats $\left(r^{2}=\right.$ $0.32, \mathrm{n}=101, \mathrm{p}<0.001)$. The 2 models are:

Marine: $\log V B R=4.97+0.51 \log c h l a-0.66 \log b a c$

$$
\mathrm{n}=78
$$

Freshwater: $\log V B R=5.20+0.51 \log c h l a-0.66 \log b a c$

$$
\mathrm{n}=23
$$

Hence, based on the adjusted mean difference, when we remove the influence of both bacterial abundance and chlorophyll concentration on the VBR, the VBR is on average 1.7 times higher in freshwater as compared with marine sites. 
Table 1. Summarv statistics. Mean, maximum, and minimum values of virus abundance (virus particles ml-1), bacterlal abundance (cells $\mathrm{ml}$ ), chlorophyll a concentrations $\left(\mu \mathrm{g}^{-1}\right)$ for fresh and marne systems. The virus-to-bacteria ratio (VBR) is expressed in terms of mode with maximum and minimum values. na: not applicable

\begin{tabular}{|c|c|c|c|c|c|c|c|}
\hline & \multicolumn{3}{|c|}{ - Freshwater } & \multicolumn{3}{|c|}{ - Marine } & \multirow{2}{*}{$\begin{array}{l}\text { Overall } \\
\text { mean }\end{array}$} \\
\hline & Mean & Max & Min & Mean & Max & Min & \\
\hline $\begin{array}{l}\text { Virus abundance } \\
\text { Corrected }\end{array}$ & $1.1 \times 10^{8}$ & $2.5 \times 10^{8}$ & $4.1 \times 10^{7}$ & $\begin{array}{l}1.7 \times 10^{7} \\
2.2 \times 10^{7}\end{array}$ & $\begin{array}{l}7.1 \times 10^{7} \\
8.0 \times 10^{7}\end{array}$ & $6.7 \times 10^{4}$ & $\begin{array}{l}3.0 \times 10^{7} \\
3.5 \times 10^{7}\end{array}$ \\
\hline Bacterial abundance & $5.8 \times 10^{6}$ & $1.6 \times 10^{7}$ & $2.4 \times 10^{6}$ & $2.0 \times 10^{6}$ & $1.4 \times 10^{7}$ & $2.3 \times 10^{4}$ & $2.6 \times 10^{6}$ \\
\hline Chlorophyll a & 9.2 & 32.8 & 1.5 & 2.5 & 12.8 & 0.05 & 5.0 \\
\hline VBR & $20-25$ & 77.5 & 4.9 & $1-5$ & 53.8 & 0.38 & na \\
\hline
\end{tabular}

In order to demonstrate the slight effect of trophy on the VBR we have plotted the rate of increase of viral abundance with chlorophyl] concentration (model 4) and the rate of increase of bacteria with increasing chlorophyll (Fig. 10). The relations are similar, although the relationship with viruses has a slightly steeper slope. The overall relationship for bacteria and chlorophyll is:

$\log b a c=6.08+0.66 \log c h l a \quad r^{2}=0.79, n=101$

When viruses were added to this relationship in a multiple regression, both parameters had a positive, significant influence on bacterial abundance. The model for this relationship is:

$$
\begin{gathered}
\log b a c=4.48+0.48 \log c h l a+0.22 \log \text { vir } \\
\mathrm{r}^{2}=0.81, \mathrm{n}=101
\end{gathered}
$$

\section{DISCUSSION}

The objective of this study was to model changes in viral abundance with the parameters which affect bacterial production. Viral abundance and algal biomass appear to be quantitatively linked in aquatic ecosys-

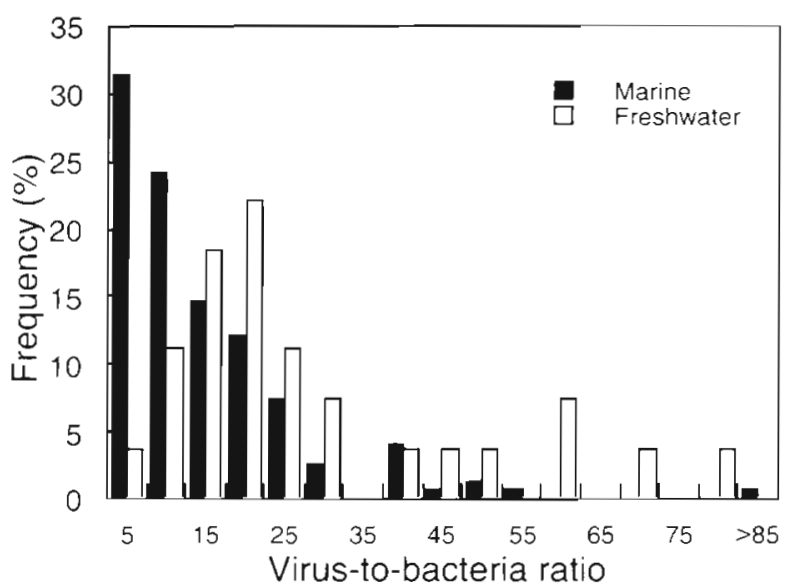

Fig. 7 Frequency distribution, represented as a percentage, of virus-to-bacteria ratios observed in marine and freshwaters tems. Chlorophyll a explained more of the variation in viral abundance in aquatic systems than did bacterial abundance. Cochlan et al. (1993) found bacterial abundance to be a superior predictor variable over chlorophyll $a$. In their models, bacterial abundance explained $69 \%$ of the variation in viral abundance as opposed to chlorophyll explaining only $45 \%$. A greater range in both trophic status and bacterial abundance is considered in this study, due to the addition of freshwater data, making chlorophyll a a slightly better predictor variable in estimating changes in viral abundance.

According to our values, there was no significant change in viral abundance with increasing bacterial abundance in freshwater, whereas there was a positive relationship with chlorophyll a. A simple explanation for this observation is that the observed increase in virus numbers with algal biomass is due to an increase in the number of algal or cyanobacterial viruses. Unfortunately there is currently no method to distinguish between algal or cyanobacterial, and bacterial viruses by microscopy. The importance of algal viruses

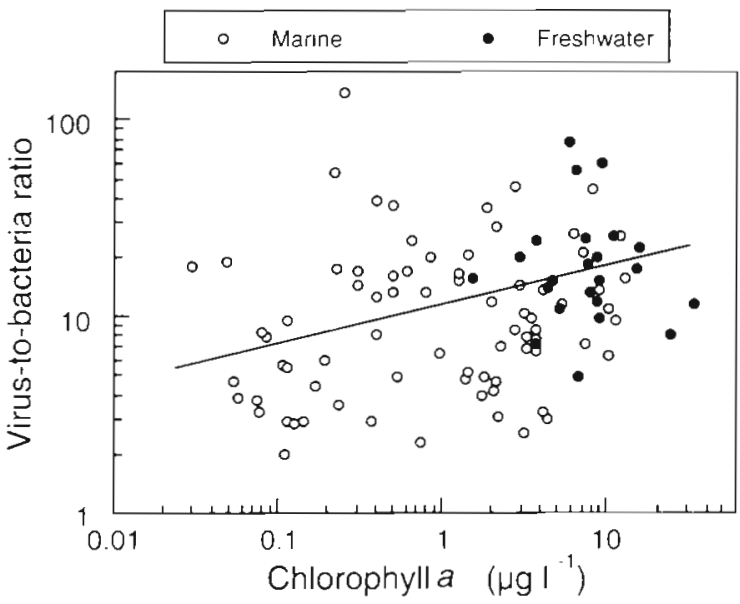

Fig. 8. Overall relationship between the virus-to-bacteria ratio and chlorophyll $a$. Solid line represents the regression equation $\left(r^{2}=0.08, n=101, p<0.05\right)$ 


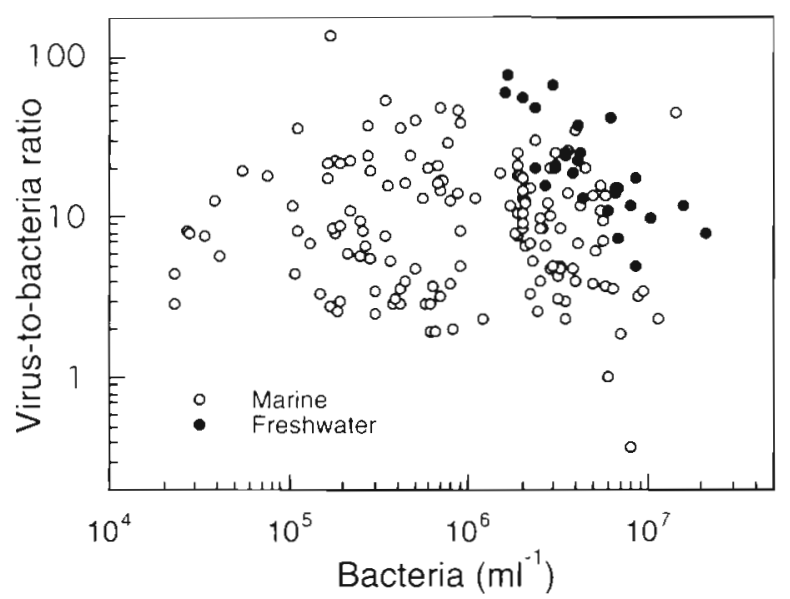

Fig. 9. Scatter diagram of VBR and bacterial abundance. This relationship was not statistically significant

remains an important open question. Alternatively, the explanation we favor is that the temporal dynamics of the relationship between bacteriophage and bacteria within a lake is inevitably negative in the short term hiding the quantitative dependence of viruses on bacteria. Hence a large trophic range is necessary in order to demonstrate a positive trend among systems. The positive effect of increasing algal biomass on the abundance of both bacteria and viruses reflects the availability of resources for bacterial production, whereas the fundamental interdependence of viruses and their bacterial hosts is obscured.

The effect of trophy on viral densities is probably related to an increase in bacterial production, and

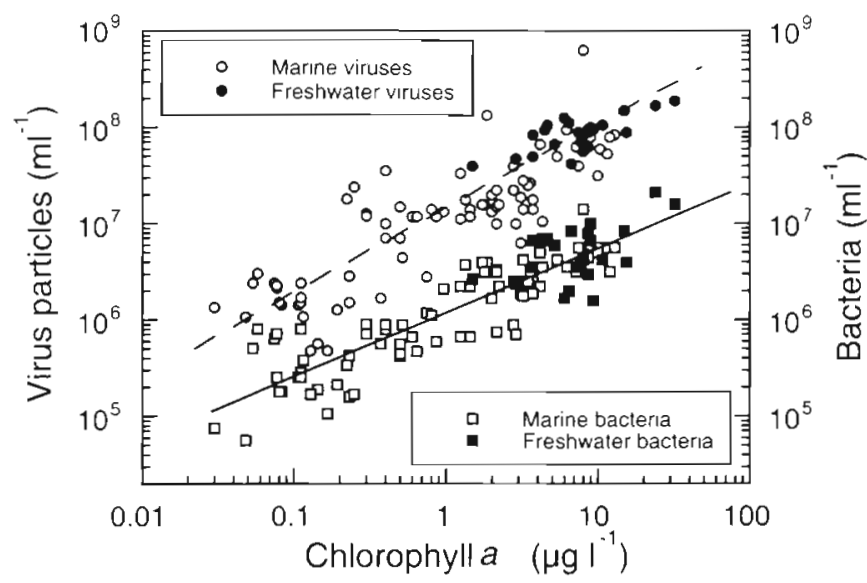

Fig. 10. Relationships between viral and bacterial abundances and chlorophyll $a$. The dotted line represents the line of best fit for the virus-chlorophyll a relationship, the solid line represents the line of best fit for the bacteria-chlorophyll $a$ relationship $\left(r^{2}=0.79, n=101, p<0.0001\right)$ for the same sites many of the viruses produced in areas with elevated algal biomass may be the product of the more active members of the bacterial community. We observed an increase in viral abundance with increasing bacterial production. It is also interesting to note that the rates of increase in viral abundance in relation to chlorophyll $a$, bacterial production and total phosphorus are virtually identical in freshwater, suggesting that these parameters all represent the same influence, the suitability of the lake for nurturing bacterial growth.

It is useful to compare these empirical results with the current quantitative understanding of phagebacterial dynamics. Weinbauer \& Peduzzi (1994) estimated average infection rates and burst sizes for different morphological types of bacteria in the Adriatic Sea, that were not much different from others reported in the literature. Summing, over morphological types, the product of the proportion of each type in the community, times the proportion observably infected. times mean burst size, times the correction factor relating total infection rate to observable infection rate, one can calculate that about 300 viruses are released per 100 native bacteria per lytic cycle. In general, the lytic cycle of viruses corresponds to the bacterial generation time or slightly longer (Proctor et al. 1993). At steady state, the VBR is equal to the ratio of viral production to viral loss. Therefore the steady state VBR would be 3 if viral loss per bacterial generation time were $100 \%$. The mean marine VBR was 10, suggesting that the turnover time for viruses is roughly 3 times bacterial generation time. The much greater VBRs seen in some environments must stem from greater infection rates or lower losses - up to 25 times longer persistence in the environment than their bacterial hosts.

It is possible that more active bacteria, growing in favorable conditions, for example those growing in areas of elevated concentrations of phytoplankton, are more susceptible to lysis induced by viral infection than those growing in nutrient-poor environments. It has been demonstrated, for the lambda phage of Escherichia coli, that the lytic pathway is favored over lysogeny under ideal growth conditions because of the reduction in the production of phage repressor protein (Watson et al. 1987). Viral control of active bacterial populations may be partly responsible for the competitive disadvantage of bacteria with respect to phytoplankton for nutrients in more eutrophic sites (Currie \& Kalff 1984). Viruses may be responsible for maintaining the bacterial population at relatively low densities by lysing its more active members, making the entire community less competitive for inorganic phosphorus. Selective viral attack on the fastest-growing bacteria has been suggested to be responsible for observations of viral abundance peaks that precede bacterial peaks in time (Maranger et al. 1994). 
Temperature may also be an important factor in controlling viral abundance in that temperature controls bacterial growth rates and has a significant positive effect on bacterial production (White et al. 1991). Jiang \& Paul (1994) found a positive correlation between viral abundance and temperature. In situ temperature was taken in our study and had no effect on viral abundance, but temperature only varied by $3^{\circ} \mathrm{C}$ among lakes during this study.

Increasing viral abundances in areas of higher trophic status may be related to an increase in burst size per lytic event, since the VBR is loosely related to increasing chlorophyll a concentrations. By simulating richer environmental growth conditions, Kokjohn et al. (1991) demonstrated that more progeny phage were produced per lysed cell than in nutrient-poor conditions. Also, Weinbauer et al. (1993) directly observed an increase in the number of assembled phage particles inside bacteria growing in more eutrophic sites.

An interesting possibility is that the consistently lower VBR observed in marine systems as compared to freshwater is an effect of salinity differences. A negative relationship appears to exist between viral abundance and increasing salt concentrations (Paul et al. 1993, Jiang \& Paul 1994). There is evidence that bacterial production also declines with increasing salinity (White et al. 1991) which might explain a part of the difference. However, we suggest that the decline results from elevated loss rates due to nonspecific adsorption to particles, which is apparently a major viral loss factor in marine coastal waters (Suttle \& Chen 1992) and which increases in direct proportion to salinity (Valentine \& Allison 1959). If this idea is correct, then the VBR in saline lakes will be found to be very low.

Alternatively, there is another major difference between marine and freshwater environments: the greater relative abundance of cyanobacteria in lakes. Prokaryotic photosynthetic biomass in marine systems is primarily picoplanktonic (Prochlorococcus and Synechococcus spp.), and may be included in the heterotrophic bacterial counts. Freshwater prokaryotic biomass can be predominantly algal, especially in richer lakes, so that the VBR in lakes is an overestimate because not all of the 'bacteria' are included in the bacterial count.

There was no apparent trend in viral size class distribution with changes in trophic status. In each of the lakes surveyed, greater than $80 \%$ of the viruses were $<70 \mathrm{~nm}$ in diameter. This may be due to grazing pressure on larger virus particles (González \& Suttle 1993). Since the viral community is a product of the host community because of the specificity of viral infection, differences in the community of viruses may imply differences in the bacterial community. It is highly probable that there were differences in the composition of the bacterial community or in the dominant active bacterial species between lakes. However, this aspect of bacterial and viral dynamics in aquatic systems cannot be studied by direct microscopy, but must await the development of novel, perhaps molecular biological, approaches to bacterial and viral identification.

That the relationship between viral and bacterial abundances in freshwater was statistically non-significant does not necessarily imply that these parameters are not related. First of all, viruses are apparently more variable in abundance than bacteria. A greater variability in viral abundance as compared with bacteria has been demonstrated in daily (Bratbak et al. 1990) and diel (Jiang \& Paul 1994) time-series studies. This greater variability in viral abundance may be due in part to a virus population's lysogenic response to given environmental conditions. Some $90 \%$ of known viruses have been identified as being temperate, and it has been suggested that (1) a depletion in nutrients in the growth medium and (2) a high multiplicity of infection (Friefelder 1987) would stimulate viral lysogenic incorporation. This would imply that lysogeny would be favored in oligotrophic sites and when the VBR is very high. The nature of the virus-host relationship, which is essentially a predator-prey relationship, may also explain the higher variability of viral abundance than of bacteria. Because viral proliferation results in host cell lysis, one would expect to observe a negative relationship between viral and bacterial abundances on a short enough time scale. Furthermore, the lysis of 1 infected bacterial cell in aquatic assemblages may produce anywhere from 6 to 124 (average 48) progeny phage (Weinbauer \& Peduzzi 1994). Hence the loss of relatively few bacterial cells to lysis induced by viral infection would produce considerably more virus particles. Virus-to-bacteria ratios vary diurnally and as a result, the viral contribution to bacterial mortality should be estimated on a time scale of hours (Jiang \& Paul 1994). Thus single observations per site would not fully describe the relationship between viral and bacterial abundance.

The relationship between viral abundance and DOC was not statistically significant in this study. However, DOC variation does not appear to influence bacterial production, which is more dependent on chlorophyll a and phosphorus concentrations in Québec lakes (Del Giorgio \& Peters 1993). DOC has a strong influence on bacterial production in Swedish lakes (Tranvik 1992). The range of DOC observed in these lakes is much greater than what is abserved in Québec lakes, and the inverse is true for chlorophyll and phosphorus concentrations. It is therefore possible that viral abundance is correlated with DOC concentration in lakes where DOC has a strong influence on bacterial production. 
The models presented here confirm that viral abundance is a predictable parameter among aquatic systems over a large trophic range. Abundances appear to be strongly affected by those parameters which control bacterial production. There is some indication that viruses are more abundant in freshwater than salt, than can be explained by differences in system productivity. The virus-to-bacterium ratio varies widely, from roughly 1 to 80 , raising the interesting possibility that viruses may be the most dynamic component of aquatic communities. Current data suggest that there is very little systematic change in this ratio along a trophic gradient, however, indicating that viruses may be equally important to bacterial dynamics in all aquatic environments.

Acknowledgements. We thank Audrey Fortin and Yves Richard for their valuable field assistance, and Marie-Josée Carbonneau for analyzing total phosphorus. Samples from the LTER program in the Antarctic and the Hawaiian Ocean Time-series program were collected in collaboration with David Karl at the University of Hawaii, to whom we are very grateful. This research was funded by a Natural Sciences and Engineering Research Council operating grant (D.F.B.), a Université du Québec à Montréal student scholarship (R.M.), a Fonds pour la Formation des Chercheurs et l'Aide à la Recherche (FCAR) team grant (D.F.B., Y T Prairie, S. K. Juniper, and D. Planas), and an FCAR centre grant to the Groupe de Recherche Interuniversitaire en Limnologie (GRIL)

\section{LITERATURE CITED}

Azam F, Fenchel T, Field JG, Gray JS, Meyer-Reil LA, Thingstad F (1983) The ecological role of water column microbes in the sea. Mar Ecol Prog Ser 10:257-263

Bergh $\varnothing$, Børsheim KY, Bratbak G. Heldal M (1989) High abundances of viruses found in aquatic environments Nature 340:467-468

Brd DF, Kalff J (1984) Empirical relationships between bacterial abundance and chlorophyll concentrations in fresh and marine waters. Can J Fish Aquat Sci 41:1015-1023

Boehme J, Frischer ME, Jiang SC, Kellogg CA, Pichard S, Rose JB, Steinway C, Paul JH (1993) Viruses, bacteria, and phytoplankton in the southwestern Gulf of Mexico: distribution and contribution to oceanic DNA pools. Mar Ecol Prog Ser 97:1-10

Børsheim KY, Bratbak G, Heldal M (1990) Enumeration and biomass of planktonic bacteria and viruses by transmission electron microscopy. Appl environ Microbiol 56: 352-356

Bratbak G, Heldal M, Norland S, Thingstad TF (1990) Viruses as partners in spring bloom trophodynamics. Appl environ Microbiol 56:1400-1405

Cochlan WP, Wikner J, Stewart GF, Smith DC, Azam F (1993) Spatial distribution of viruses, bacteria and chlorophyll a in neritic, oceanic and estuarine environments. Mar Ecol Prog Ser 82:151-162

Cole J, Findlay S, Pace M (1988) Bacterial production in fresh and saltwater ecosystems: a cross system overview. Mar Ecol Prog Ser 43:1-10
Currie D, Kalff J (1984) The relative importance of phytoplankton and bacterioplankton in phosphorus uptake in freshwater. Limnol Oceanogr 29:298-310

Del Giorgio PA, Peters RH (1993) The influence of DOC on the bacteria-chlorophyll relationship in lakes. Verh int Verein Limnol 25:359-362

Fenchel T (1982) Ecology of heterotrophic microflagellates. IV. Quantitative occurrence and importance as bacterial consumers. Mar Ecol Prog Ser 9:35-42

Freifelder D (1987) Microblal genetics. Jones and Bartlett, Boston

González JM, Suttle CA (1993) Grazing by marine nanoflagellates on viruses and virus-sized particles: ingestion and digestion. Mar Ecol Prog Ser 94:1-10

Hammond GW, Hazelton PR, Chuang I, Klisko B (1981) Improved detection of viruses by electron microscopy after direct ultracentrifuge preparation of specimens. $\mathrm{J}$ clin Microbiol 14:210-221

Hara S, Terauchi K, Koike I (1991) Abundance of viruses in marine waters: assessment by epifluorescence and transmission electron microscopy. Appl environ Microbiol 57 : 2731-2734

Heldal M. Bratbak G (1991) Production and decay of viruses in aquatic environments. Mar Ecol Prog Ser 72:205-212

Jiang SC, Paul JH (1994) Seasonal and diel abundance of viruses and occurrence of lysogeny/bacteriocinogeny in the marine environment. Mar Ecol Prog Ser 104:163-172

Kirchman DL, K'nees E, Hodson RE (1985) Leucine incorporation and its potential as a measure of protein synthesis by bacteria in natural aquatic systems. Appl environ Microbiol 49:599-607

Klut ME, Stockner JG (1990) Virus-like particles in an ultraoligotrophic lake on Vancouver Island, British Columbia. Can J Fish Aquat Sci 47:725-730

Kokjohn TA, Sayler GS, Miller RV (1991) Attachment and replication of Pseudomonas aeruginosa bacteriophages under conditions simulating aquatic environments. J chn Microbiol 137:661-666

Maranger R, Bird DF, Juniper SK (1994) Viral and bacterial dynamics in Arctic sea ice during the spring algal bloom, near Resolute, NWT, Canada. Mar Ecol Prog Ser 111. $121-127$

McManus GB, Fuhrman JA (1986) Bacterivory in sea water studied with the use of inert fluorescent particles. Limnol Oceanogr 31:420-426

Pace ML (1988) Bacterial mortality and the fate of bacterial production. Hydrobiologia 159:41-49

Paul JH, Jiang SC, Rose JB (1991) Concentration of viruses and dissolved DNA from aquatic environments by vortex flow filtration. Appl environ Microbiol 57:2197-2204

Paul JH, Rose JB, Jiang SC, Kellogg CA, Dickson L (1993) Distribution of viral abundance in the reef environment of Key Largo, Florida. Appl environ Microbiol 59:718-724

Porter KG, Feig YS (1980) The use of DAPI for identifying and counting aquatic microflora. Limnol Oceanogr 25 943-948

Proctor LM, Fuhrman JA (1990) Viral mortality of marine bacteria and cyanobacteria. Nature 343:60-62

Proctor LM, Okubo A, Fuhrman JA (1993) Calibrating estimates of phage-induced mortality in marine bacteria ultrastructural studies of marine bacteriophage development from one-step growth experiments. Microb Ecol 25 $161-182$

SAS Institute Inc. (1987) SAS/STAT guide for personal computers, Version 6 edn. SAS Institute Inc, Cary, NC

Sherr BF, Sherr EB, Pedrós-Alió C (1989) Simultaneous measurements of bacterioplankton production and proto- 
zoan bacterivory in estuarine water. Mar Ecol Prog Ser $54: 209-219$

Smith DC, Steward GF, Azam F (1992) Virus and bacteria abundances in the Drake Passage during January and August 1991. Antarct J US 46:125-127

Suttle CA, Chan AM, Cottrell MT (1990) Infection of phytoplankton by viruses and reduction of primary productivity. Nature 347:467-469

Suttle CA, Chen F (1992) Mechanisms and rates of decay of marine viruses in seawater. Appl environ Microbiol 58: $3721-3729$

Suttle CA, Chan AM (1994) Dynamics and distribution of cyanophages and their effect on marine Synechococcus spp. Appl environ Microbiol 60:3167-3174

Tranvik LJ (1992) Allochthonous dissolved organic matter as an energy source for pelagic bacteria and the concept of the microbial loop. Hydrobiologia 229:107-114

Valentine RC, Allison AC (1959) Virus particle adsorption I. Theory of adsorption and experiments on the attachment of particles to non-biological surfaces. Biochim Biophys Acta 34:10-23

Watson JD, Hopkins NH, Roberts JW, Steitz JA, Weiner A

This article was submitted to the editor
(1987) Molecular biology of the gene, 4th edn. The Benjamin/Cummins Publishing Company Inc, California

Weinbauer MG, Fuks D, Peduzzi P (1993) Distribution of viruses and dissolved DNA along a coastal trophic gradient in the Northern Adriatic Sea. Appl environ Microbiol 59:4074-4082

Weinbauer MG, Peduzzi P (1994) Frequency, size and distribution of bacteriophages in different marine bacterial morphotypes. Mar Ecol Prog Ser 108:11-20

Wetzel RG, Likens GE (1991) Limnological analyses, 2nd edn. Springer-Verlag, New York

White PA, Kalff J, Rasmussen JB, Gasol JM (1991) The effect of temperature and algal biomass on bacterial production and specific growth rate in freshwater and marine habitats. Microb Ecol 21:99-118

Wicks RJ, Robarts RD (1988) Ethanol extraction requirements for purification of protein labelled with ${ }^{3} \mathrm{H}$ leucine in aquatic bacterial production studies. Appl environ Microbiol 54:3191-3193

Wommack KE, Hill RT, Kessel M, Russek-Cohen E, Colwell RR (1992) Distribution of viruses in the Chesapeake Bay. Appl environ Microbiol 31:415-422

Manuscript first received: August 8, 1994

Revised version accepted: January 21, 1995 